\title{
Superoxide dismutase, glutathione peroxidase and catalase activities in patients with viral hepatitis $\mathrm{C}$
}

\author{
Yalcin MS ${ }^{*}$, Gulesci $\mathrm{N}^{2}$, Bilgin $\mathrm{R}^{3}$ and Koltas IS ${ }^{4}$ \\ ${ }^{1}$ Department of Chemical and Chemical Processing Technologies, Technical Science Vocational School, Mersin University, Mersin, Turkey \\ ${ }^{2}$ Department of Chemical and Chemical Processing Technologies, Gumushane Vocational School, Gumushane University, Gumushane, Turkey \\ ${ }^{3}$ University of Cukurova, Arts \& Science Faculty, Chemistry Department, Adana, Turkey \\ ${ }^{4}$ Cukurova University, Faculty of Medicine, Department of Medical Parasitology, Adana, Turkey
}

\begin{abstract}
Purpose: Aerobic organisms possess antioxidant defense systems that deal with reactive oxygen species (ROS) produced as a consequence of aerobic respiration and substrate oxidation. It is considered that free radicals, lipid peroxidation and antioxidant defense play a role in various tissue damages, just as in certain types of viral hepatitis.
\end{abstract}

Materials and methods: We determined SOD, CAT, GPX activities of $18 \mathrm{HCV}$ subjects and matched their values with that of 18 healthy volunteers as control. The patients were diagnosed by physicians on the basis of detailed clinical history, clinical examination and other relevant biochemical investigations.

Results: SOD, CAT and GPX activities in patients with $\mathrm{HCV}$ were found as (mean $\pm \mathrm{SD}$ ) $2.75 \pm 0.75 \mathrm{U} / \mathrm{mg} \mathrm{prot}, 19.25 \pm 3.4 \mathrm{U} / \mathrm{g} \mathrm{Hbx} 10^{4}, 78.25 \pm 23.23 \mathrm{U} / \mathrm{g} \mathrm{Hb}$ respectively, whereas for the control group $3.76 \pm 1.53 \mathrm{U} / \mathrm{mg}$ prot, $13.71 \pm 1.6 \mathrm{U} / \mathrm{g} \mathrm{Hbx} 10^{4}, 63.26 \pm 6.9 \mathrm{U} / \mathrm{g}$ Hb were observed for the respective enzymes.

Conclusion: Our results show the mild impact of hepatitis $\mathrm{C}$ on antioxidant status of the person. There is a reduction in SOD level but an increase in CAT and GPX levels. In this study also suggests some possible role of oxidative stress in the mechanism of liver injury during viral hepatitis.

\section{Introduction}

Aerobic organisms produce reactive oxygen species (ROS) as a consequence of aerobic respiration and substrate oxidation. Low levels of ROS are helpful in many processes including cell differentiation, cell growth, apoptosis, immunity and defence against micro-organism. In contrast, high levels of ROS result in oxidative stress, which may cause metabolic malfunction and macromolecular, cellular and tissue damages. In order to deal with damaging activities of ROS, aerobic organisms process antioxidant defence systems. The enyzmatic antioxidant defences include SOD, GPX and CAT [1-5].

SOD is an enzyme that catalyzes the dismutation of two superoxide anions $\left(\mathrm{O}_{2}^{-}\right)$into hydrogen peroxide and molecular oxygen. It protects the tissue to a certain degree from the harmful effects of superoxide radicals. CAT enzyme hydrolyses hydrogen peroxide $\left(\mathrm{H}_{2} \mathrm{O}_{2}\right)$ into water and molecular oxygen. GPX catalyses the reduction of hydroperoxides using glutathione (GSH). In fact, glutathione metabolism is one of the most essential antioxidative defense mechanisms [6,7].

The activity of these enzymes plays an important role in the progress of the disease, therefore in the treatment of chronic HCV, antioxidant treatment may useful and should be added to combined therapy for these patients.

Hepatitis $\mathrm{C}$ virus is the main causative agent of chronic viral hepatitis. Chronic HCV can progress to cirrhosis and eventually to hepatocellular carcinoma over a period of 20-30 years. The mechanism by which HCV causes cell damage are not well understood. Different mechanisms including immunological liver damage, direct cytotoxicity mediated by different viral products and induction of oxidative stress have been suggested as playing pathogenic role in this infection [6].

The aim of this study was to examine the relationship between chronic HCV and oxidant/antioxidant status. For this purpose we investigated levels of erythrocyte SOD, CAT and GPX as an antioxidant enzymes in the patient with HCV and the results were compared with that of healthy same aged controls.

\section{Materials and methods}

We assayed SOD, CAT and GPX activities of 18 subjects who were diagnosed with chronic viral hepatitis aged between 41-55 years (9 males and 9 females). Group who had no antiviral treatment and also the relationship of these parameters with viral load, fibrosis score and necro-inflammation of the liver. None of them was smoker, and had any known pathologies and taking steroids or medications such as iron for anemia at the time of sampling. Serum samples for control group were obtained from 18 healthy subject. All subjects fasted after midnight before blood collection the next morning.

${ }^{\star}$ Correspondence to: Serkan Yalcin M, Department of Chemical and Chemical Processing Technologies, Technical Science Vocational School, Mersin University, Mersin, Turkey, E-mail: serkanyalcin@mersin.edu.tr

Key words: hepatitis C, antioxidants, superoxide dismutase, glutathione peroxidase, catalase

Received: March 19, 2020; Accepted: April 06, 2020; Published: April 10, 2020 
The study took place in the Faculty of Medicine, University of Cukurova, Balcali Hospital in Adana, Turkey. It was approved by the Committee for Ethics of Medical Experiment on Human Subjects, Faculty of Medicine, Cukurova University, Adana. Submission of the individuals to the study was conditioned by an obtained written informed consent form. The study proceeded in agreement with the Helsinki declaration approved on the World Medical Association meeting in Edinburgh (Ethics decision number: 2008/11).

The mean age of the women and men in the patient group were $47.7 \pm 4.8$ years and $47.7 \pm 3.0$ years, respectively. The mean age of the women and men in the control group were $47.6 \pm 5.5$ years and $47.3 \pm 4.5$ years respectively.

\section{Viral load and histopatological findings}

The viral load was assayed using a polymerase chain reaction technique. Histopathologic findings in the liver were scored as necroinflammatory activity and fibrosis according to Ishak-Knodell score.

\section{Biochemical assay}

All venous blood samples taken between 8 and 9 a.m. after $8 \mathrm{~h}$ of fasting were collected in polystyrene tubes and vacutainers containing heparin. The tubes were centrifuged at $1500 \mathrm{rpm}$ for $15 \mathrm{~min}$. Sera were then removed and stored at $-20^{\circ} \mathrm{C}$ until analysis.

\section{Determination of SOD activity}

SOD activity was determined according to the method of Sun et al. [8]. This assay for SOD activity involves inhibition of nitroblue tetrazolium reduction, with xanthine-xanthine oxidase used as a superoxide generator. The production of formazan was determined spectrophotometrically at $560 \mathrm{~nm}$.

\section{Determination of CAT activity}

CAT activity was determined according to the Lartillot et al. [9] which is a modification of the method described by Bergmeyer [10]. CAT activity was measured spectrophotometrically at $240 \mathrm{~nm}$ using a specific absorption. CAT activity determined in the reaction mixture containing $2.5 \mathrm{ml}$ of substrate made up of $10 \mathrm{mM}$ hydrogen peroxide in a $50 \mathrm{mM}$ phosphate buffer $\mathrm{pH}$ 7.0. The reaction was carried out at $25^{\circ} \mathrm{C}$ for $2 \mathrm{~min}$ and stopped by adding $0.5 \mathrm{ml}$ of $1 \mathrm{M} \mathrm{HCl}$. The activity of CAT was given as $(\mathrm{U} / \mathrm{gHb}) \times 10^{4}$

\section{Determination of hemoglobin}

The hemoglobin assay was determined according to the method of White et al. [11].

\section{Determination of GPX activity}

GPX activity was determined according to the method of Beutler E [12]. GPX estimation is based on the following principle: GPX catalyses the oxidation of glutathione by cumen hydroperoxide. In the presence of glutathione reductase and NADPH the oxidized glutathione is immediately converted to the reduced form with a concomitant oxidation of NADPH to $\mathrm{NADP}^{+}$. The decrease in absorbance at $340 \mathrm{~nm}$ is measured.

\section{Statistical analysis}

Statistical analysis was performed with SPSS software package (Version 11.0 for Windows). The data were expressed as mean \pm standard deviation (SD). For comparison of two groups of continuous variables, independent sample $t$-test was used. A probability value of $P<0.05$ indicated a statistically significant difference.

\section{Results}

SOD, CAT and GPX activities of the patients with HCV and control group were found as ( mean $\pm \mathrm{SD}$ ) $2.75 \pm 0.75 \mathrm{U} / \mathrm{mg}$ prot., $19.25 \pm 3.4 \mathrm{U} / \mathrm{g}$ $\mathrm{Hbx} 10^{4}, 78.25 \pm 23.23 \mathrm{U} / \mathrm{g} \mathrm{Hb}$ and $3.76 \pm 1.53 \mathrm{U} / \mathrm{mg}$ prot, $13.71 \pm 1.6 \mathrm{U} / \mathrm{g}$ $\mathrm{Hbx} 10^{4}, 63.26 \pm 6.9 \mathrm{U} / \mathrm{g} \mathrm{Hb}$, respectively (Table 1 ).

Additionally, no significant correlation was found between these markers and viral load ( $>0.05$ ), necro-inflammation, and fibrosis of the liver in patients with chronic viral hepatitis. Genotypes were correlated with demographic, clinical and histological features. All patients were infected with type 1 .

\section{Discussion}

The reports from several studies have produced a clear evidence that there exist a good correlation between type and severity of disease and antioxidant level in the blood. Such relations have been documented in many diseases including cardiovascular diseases, neurological diseases, pulmonary diseases and various types of malignancies [1].

In this study, it was determined that SOD activities in patients with HCV were significantly lower than that of controls $(\mathrm{p}<0.05)$. Studies by Yasuyama et al. reported decrease of SOD levels in liver tissue in patients with acute and chronic hepatitis accompanied by fatty degeneration while comparing with patients with liver inflammatory diseases of different etiology [13]. It seems that development of some diseases is possible due to decreased SOD level. It is verified by experiments conducted by Li. He showed that mice without gene that codes MnSOD died 10 days after birth with developed cardiomyopathy, lipid accumulation in liver and skeletal muscles [14]. Decrease of superoxide dismutase level in biopsy specimen may suggest the release of the enzyme from damaged hepatocytes or decreased synthesis. Interaction of antioxidant enzymes is effective when their activities remain in defined proportions. The activity change of just one of them disturbs equilibrium and it may be the reason of neoplastic transformation of cells.

There are conflicting results in previous studies by several researchers. Irshad et al. [1] and Karabulut et al. [6] reported decreased SOD activity in chronic hepatitis $\mathrm{C}$ patients. On the other hand, Ko et al. [15] reported increased SOD activity in HCV. Our results agree with the results of these reports $[1,6]$.

Oberley and Sun presented the hypothesis that assumes that cells with low SOD and CAT levels and changeable activity of GPX and elevated activity of GST are selected from normal cells and ultimately form neoplasm [16]. The relation between the mechanisms and carcinogenesis is not explained. On the basis of experimental models it was explained that oxidative stress may lead to neoplastic transformation. Therefore, occurrence of primary hepatic cancer in the course of cirrhosis of HBV and HCV etiology may be associated with disturbances of antioxidant barrier equilibrium of the organism.

Table 1. SOD, CAT and GPX activities in patients with HCV and controls

\begin{tabular}{|c|c|c|c|c|c|}
\hline Parameters & n & Ages (years) & $\begin{array}{c}\text { SOD } \\
(\mathrm{U} / \mathrm{mg} \text { Prot.) }\end{array}$ & $\begin{array}{c}\text { CAT } \\
(\mathrm{U} / \mathrm{gHb}) \times 10^{4}\end{array}$ & $\begin{array}{c}\text { GPX } \\
(\mathrm{U} / \mathrm{gHb})\end{array}$ \\
\hline Controls & 18 & $47,5 \pm 4,9$ & $3,76 \pm 1,53$ & $13,71 \pm 1,6$ & $63,26 \pm 6,9$ \\
\hline Patients & 18 & $47,8 \pm 3,9$ & $2,75 \pm 0,75$ & $19,25 \pm 3,4$ & $78,25 \pm 23,2$ \\
\hline \multicolumn{7}{|r}{} & $\mathrm{p}<0.05$ & $\mathrm{p}<0.0001$ & $\mathrm{p}<0.05$ \\
\hline
\end{tabular}


On the other hand, a statistically significant was found increase in CAT activities in patients with HCV compared with control group $(\mathrm{p}<0.0001)$. A significant increase were also found in GPX activities in patients with HCV compared with control group $(\mathrm{p}<0.05)$

Chrobat et al. [17] reported that decreased SOD and CAT activity and increased GPX activity in children with chronic viral hepatitis B and C. Boya, et al. [18] found no difference between the CAT activity of the patients with HCV and control group, in contrast, Karabulut et al. [6] reported increased CAT activity in chronic in HCV patients.

Czeczot et al. [19] reported increased GPX activity in cirrhosis, in contrast, Ko et al. [15] found decreased GPX activity in viral hepatitis. On the other hand, Czuczejko, et al. [20] reported no difference between in GPX activity patients with HCV and control group.

\section{Conclusion}

These results show the mild impact of hepatitis $\mathrm{C}$ on antioxidant status of the person. There is a reduction in SOD level, but an increase in CAT and GPX levels. In this study also suggests some possible role of oxidative stress in the mechanism of liver injury during viral hepatitis.

\section{Acknowledgment}

This work supported by Research Grant from FEF. BAPYL19 Cukurova University.

\section{References}

1. Irshad M, Chaudhuri PS, Joshi YK (2002) Superoxide dismutase and total anti-oxidant levels in various forms of liver diseases. Hepatol Res 23: 178-184. [Crossref]

2. Hurst R, Bao Y, Jemth P, Mannervik B, Williamson G (1997) 3-Phospholipid hydroperoxide glutathione peroxidase activity of rat class Theta glutathione transferase T2-2. Biochem Soc Trans 25: 559.

3. Jornot L, Peterson H, Junod AF (1998) Hydrogen peroxide-induced DNA damage is independent of nuclear calcium but dependent on redox-active ions. Biochem Journal 335: 85-94. [Crossref]

4. Ghosh J, Myers CE (1998) Inhibition of arachidonate 5-lipoxygenase triggers massive apoptosis in human prostate cancer cells. Proc Natl Acad Sci 95: 13182-13187. [Crossref]
5. Bae YS, Kang SW, Seo MS, Baines IC, Tekle PB, Rhee SG (1997) Epidermal growth factor (EGF)-induced generation of hydrogen peroxide role in EGF receptor-mediated Tyrosıne Phosphorylation. J Biological Chem 272: 217-21.

6. Karabulut AY, Sonmez E, Bayındır Y, Gozukara E (2002) A comparison of erythrocyte superoxide dismutase and catalase activity in patients with hepatitis $\mathrm{C}$ infection. Turk J Med Sci 32: 313-316.

7. Mates JM, Gomez CP, De Castro IN (1999) Antioxidant enzymes and human diseases. Clinical Biochemistry 32: 595-603.

8. Sun YI, Oberley LW, Li Y (1998) A simple method for clinical assay of superoxide dismutase. Clinical Chemistry 34: 97-500. [Crossref]

9. Lartillot S, Kedziora P, Athias A (1988) Purification and characterization of a new fungal catalase. Prep Biochem 18: 241-246. [Crossref]

10. Bergmeyer HU (1974) Methods of enzymatic analysis. New York: Academic pres 1: 438

11. White WL, Erickson M, Stevens SC (1976) Determination of total protein and albumin chemistry for clinical laboratory. The CV Mosby Company, St Louis Mo 183.

12. Beutler E (1975) Red cell metabolism: a manual of biochemical methods. Grune \& Starton, 160 pages.

13. Yasuyama T, Inoue K, Kojima T, Sasaki H (1988) Activities, electrophoretic profiles and immunolocalization of superoxide dismutase in human liver specimens. Jpn J Med 27: 34-41. [Crossref]

14. Li Y, Huang TT, Carlson EJ (1995) Dilated cardiomyopathy and neonatal lethality in mutant mouse lacking manganese superoxide dismutase. Nat Genet 11:376-381.

15. Sun Y, Oberley LW, Elwell JH, Sierra-Rivera E (1989) Antioxidant enzyme activities in normal and transformed mouse liver cells. Int J Cancer 44: 1028-1033. [Crossref]

16. Ko WK, Guo CH, Yeh MS, Lin LY, Hsu GSW, et al. (2005) Blood micronutrient oxidative stress and viral load in patients with chronic hepatitis C. World J Gastroenterol 11: 4697-4702.

17. Chrobot AM, Szaflarska-Szczepanik A, Drewa G (2000) Antioxidant defense in children with chronic viral hepatitis B and C. Med Sci Monit 6: 713-718. [Crossref]

18. Boya P, Pefia A, Beloqui O, Larrea E, Conhilli M, et al. (1999) Antioxidant status and glutathione metabolism in peripheral blood mononuclear cells from patients with chronic hepatitis C. Journal of Hepatol 31: 808-814. [Crossref]

19. Czeczot H, Scibior D, Skrzycki M, Podsiad M (2006) Glutathione and GSH-dependen enzymes in patients with liver cirrhosis and hepatocellular carcinoma. Acta Biocheim Pol 53: 237-241.

20. Czuczejko J, Zachara B, Topczewska ES, Halota W, Kedziora J (2003) Selenium, glutathione and glutathione peroxidases in blood of patients with chronic liver diseases. A Biochem Pol 50: 1147-1154. [Crossref]

Copyright: (C2020 Yalcin MS. This is an open-access article distributed under the terms of the Creative Commons Attribution License, which permits unrestricted use, distribution, and reproduction in any medium, provided the original author and source are credited. 